\title{
Synthesis and Physico-Chemical Evaluation of Polyurethane Microstructures for Transmembrane Delivery of Reynoutria japonica Extract
}

\author{
FLORINA ARDELEAN ${ }^{1 *}$, RAZVAN SUSAN², FLORIN BORCAN ${ }^{1 *}$, ALINA MOACA ${ }^{1}$, DIANA SIMONA ANTAL ${ }^{1 *}$, CODRUTA SOICA $^{1}$, \\ ROXANA MOLDOVAN², DELIA BERCEANU VADUVA², DANIELA MARTI ${ }^{3}$ \\ 'Victor Babes University of Medicine and Pharmacy, Faculty of Pharmacy, 2 Eftimie Murgu Sq., 300041, Timisoara, Romania \\ 2Victor Babes University of Medicine and Pharmacy, Faculty of Medicine, 2 Eftimie Murgu Sq., 300041, Timisoara, Romania \\ 3Western University Vasile Goldis Arad, 94 Revolutiei Blvd., 310025, Arad, Romania
}

\begin{abstract}
Polymer microstructures containing plant extracts are a novel technique used to increase the bioavailability of active agents with low aqueous solubility. Japanese knotweed (Reynoutria japonica) is an invasive plant with multiple biomedical properties. The aim of the present study was to obtain and characterize polyurethane microstructures used as a drug delivery system of a Japanese knotweed extract. The results indicate the obtaining of microstructures with an almost neutral pH, with sizes between 540 and $1134 \mathrm{~nm}$, with a medium stability against the tendency to form clusters and a very good thermal stability. These first results present the potential of the obtained polyurethane microstructures as candidates for the transmembrane drug delivery of J apanese knotweed extracts, as a starting point for further bioactivity investigations.
\end{abstract}

Keywords: DSC, encapsulation efficacy, polyurethane microstructures, Reynoutria japonica, zetasizer

Japanese knotweed (Reynoutria japonica Houtt. syn. Polygonum cuspidatum Sieb. and Zucc.) is one of the plants known in Europe for its rapid reproduction and difficulteradication [1]. Native to Asia, it was introduced in Europe as an ornamental plant and now adays it is listed as one of the most invasive species [2]. Apart from being of ecological concern, the underground parts are used in Traditional Chinese Medicine. Various extracts and bioactive compounds isolated from Japanese knotweed are evaluated for their biological properties [3]. The most representative compound from the underground parts is resveratrol, intensely studied for its antioxidant, cardioprotective, anti-inflammatory and anticancer properties. This stilbene is an ingredient of healthpromoting products [4]. Other compounds including emodin, quercetin, polydatin or chlorogenic acid have been identified in the rhizomes of J apanese knotweed [5].

A major disadvantage of plant extracts is the low bioavailability. Formulation as nano- and microstructures is a modern, cost-effective approach to modulate the target delivery and pharmacokinetic parameters of drugs, including natural products [6]. Polymer-based structures used as drug delivery agents can be prepared by polymerization, by dispersion of previously formed polymers, or by ionic gelation in case of hydrophilic polymers [7]. Linkages in polyurethanes result from reactions of diisocyanates with ether and/or ester polyols; a large variety of surface modifications and attachments of biologically active compounds make these polymers highly versatile [8]. Their biomedical applications include surgical implants, tissue replacement and engineering [9], $[10,11]$ wound dressings [12], microcapsules [13] and advanced drug delivery [14], with the advantage of a high biocompatibility [15]. Polyurethane-based microstructures obtained previously with various diisocyanates (lysinediisocyanate, hexamethylene-diisocyanate, isophoronediisocyanate) pointed out that isophorone-diisocyanate yields particles with the highest stability and the most convenient toxicologic profile following evaluation in mammalian mesenchymal stem cells and topical application to hairless mice [16]. This fact motivated the choice of the same compound for polymer obtainment in the present research.

Inclusion of plant extracts in polyurethane microcapsules has been less researched until now. It was successfully performed for mistletoe and garlic extracts [17], providing eye-drops with prolonged drug-release. In case of ursolic and oleanolic acids included in polyurethanes, the chemopreventive and antibacterial effects of the triterpenes were diminished in the experimental models $[18,19]$. This fact is in agreement with the slow liberation of compounds from the polyurethane matrix, which makes these microparticles rather suitable for a retard effect. An appealing application of polyurethane drug carriers is colic targeting, and the obtainment of a polyurethane based on isophoronediisocyanate, polyethylene-glycol, 1,2-propanediol and $m, m^{\prime}$-di(hydroxymethyl)azobenzene which is specifically degraded by bacteria of the intestinal microflora has been reported [20]. On the other hand, the extract of Polygonum cuspidatum has been shown to have relevant effects for colic diseases: it inhibits the growth of human colon cancer SW 480 cells, displays anti-inflammatory and antioxidative effects $[5,21]$. Its most important component, resveratrol, is able to inhibit metastasis of colorectal cancer cells via the Wnt/â-catenin signal pathway [22]. As well, it has a favorable effect in Crohn's disease [23]. In this idea, the aim of our study was to obtain and characterize, for the first time, of polyurethane microstructures encapsulating Japanese knotweed extract. The obtained particles will be subjected to further tests concerning in vivo efficacy in experimental models of chronic colic pathologies.

\section{Experimental part \\ Reagents}

The reagents used in the study were: isophoronediisocyanate (IPDI), acetone, polyethylene-glycol (PEG $200)$ and Tween ${ }^{\circledR} 20$ from Merck (Germany), ethyleneglycol (EG), ascorbic acid from Lach-Ners.r.o. (Czech Republic), 1,1-diphenyl-2-picrylhydrazyl (DPPH) from Sigma Aldrich (Germany). 


\section{Extraction procedure}

The Reynoutriajaponica extract was prepared from dried rhizomes, with a diameter of $2-3 \mathrm{~cm}$ (thick rhizomes). The plant material was collected in summer 2016 from the wild flora of Romania, in the northwest of the country and identified at the Department of Pharmaceutical Botany, Faculty of Pharmacy Timisoara (voucher specimen

AF003). Fifty grams of grinded dried material were extracted with $1 \mathrm{~L}$ methanol in an ultrasonication bath for 20 minutes. The mixture was filtered and the solvent was removed in a rotary evaporator under reduced pressure. The procedure was repeated three times.

\section{Antioxidant activity}

The antioxidant activity was evaluated using the DPPH (1,1-diphenyl-2-picrylhydrazyl) method [24]. Different dilutions of the extract in ethanol $50 \%(1.00 \mathrm{mg} / \mathrm{mL}, 0.50$ $\mathrm{mg} / \mathrm{mL}, 0.25 \mathrm{mg} / \mathrm{mL}, 0.10 \mathrm{mg} / \mathrm{mL}$ ) were prepared, as well as an ascorbic acid solution $(0.167 \mathrm{mmol} / \mathrm{L}$ in ethanol $96 \%$ $(\mathrm{v} / \mathrm{v})$ to be used as a standard. The samples and the standard $(0.50 \mathrm{~mL})$ were mixed with $0.50 \mathrm{~mL}$ DPPH (1 $\mathrm{mmol} / \mathrm{L}$ ) and $2 \mathrm{~mL}$ ethanol $96 \%$. The absorbance was monitored for 10 minutes at $516 \mathrm{~nm}$ using a UViLine 9400 Spectrophotometer (SI Analytics, Germany). The antioxidant activity was calculated as follows: AAO \% = $100-A_{516(t)} / A_{516(t=0)} \times 100$, where AAO - Antioxidantactivity; A516 $(\mathrm{t}=0)$ - Ábsorbance determined initially at $516 \mathrm{~nm}$ (without sample); A516 ( $\mathrm{t}$ ) - Absorbance determined at $516 \mathrm{~nm}$ at a specific time.

\section{Synthesis of polyurethane (PU) microstructures}

The PU microstructures were obtained by interfacial polyaddition combined with spontaneous emulsification using a method previously described in the literature [16, $25,26]$. Briefly, the method was the following: an organic ( $1.5 \mathrm{~mL} \mid \mathrm{PD}$ I mixed with $20 \mathrm{~mL}$ acetone at room temperature) and an aqueous phase $(0.6 \mathrm{~mL}$ EG, $2.0 \mathrm{~mL}$ Tween ${ }^{\circledR} 20$ and $2.0 \mathrm{~mL}$ PEG 200 mixed with $40 \mathrm{~mL}$ distilled water at room temperature) were prepared; the organic phase was then injected into the aqueous phase under magnetic stirring (approx. $300 \mathrm{rpm}$ ), when the PU structures were formed. To ensure the maturation of microstructures walls, the stirring process was continued for four hours. In order to eliminate unwanted amines from secondary reactions between isocyanate and water, the resulting suspension was purified (three cycles of centrifugation and dispersion in a mixture water/acetone). For acetone and water removal, the suspension was kept in Petri dishes as thin layers (approx. $3 \mathrm{~mm}$ ) for more than 2 weeks, at room temperature $[16,26]$.

This procedure was employed in two similar experiments, with and without the plant extract (empty PU structures), in order to compare the characteristics of the two samples. $1 \mathrm{mg} / \mathrm{mL}$ plant extract solution in ethanol was used.

\section{Physical and chemical characterization}

The $p H$ of the samples was determined at room temperature using a portable $\mathrm{pH}$ meter (Hanna Instruments, USA) and $20 \mathrm{~mL}$ solution. The instrument was previously calibrated using three standard buffer solutions $(\mathrm{pH}=4.00$, 7.00 , and respectively 9.00 , at $25^{\circ} \mathrm{C}$ ). Prior to $\mathrm{pH}$ measurement, the electrode was rinsed repeatedly with distilled water and dried.

The size and stability of PU structures were measured using a zetasizer system (Cordouan Technol., France) composed of a Vasco Size Analyzer and a Wallis Zeta potential Analyzer. The parameters for the Size Analyzer were the following: temperature: $25^{\circ} \mathrm{C}$, time interval: between $17-23 \mu \mathrm{s}$, number of channels: $850-950$, laser power: 30-40\%, DTC position: DOWN, acquisition mode: continuous and analysis mode: Pade-Laplace. For Zeta potential Analyzer the parameters were: plastic cuvettes, temperature: $25^{\circ} \mathrm{C}$, resolution: medium, $0.8 \mathrm{~Hz}$ and Henry function: Smoluchowski.

The thermal behaviour of the PU microstructures was investigated by differential scanning calorimetry (DSC) with a DSC1 instrument (Mettler-Toledo, Switzerland) between $40-150^{\circ} \mathrm{C}$ in an oxidative atmosphere, with a heating rate of $5 \% / \mathrm{min}$, using aluminium crucibles with pierced caps. The samples weight was between 3.81-4.04 mg.

\section{Encapsulation efficacy}

The evaluation of the encapsulation efficacy was performed using a procedure previously described in the literature [27]. In brief, the free polyphenols content was determined and compared to the total amount. The free polyphenols content was detected at $246 \mathrm{~nm}$ using a UVi Line 9400 Spectrophotometer (SI Analytics, Germany) from the washing mixture used to purify the reaction products and it was calculated using a calibration curve $\left(R^{2}=0.979\right)$.

\section{Results and discussions}

Polymer structures were evaluated in previous studies as drug delivery systems for natural compounds and plant extracts $[17,18]$. The extracts from underground parts of J apanese knotweed are appreciated for their therapeutic properties evaluated in numerous studies [28]. The aim of the present study was to synthesize and to characterize PU microstructures containing Japanese knotweed rhizome extract, in view of their antioxidant, antiinflammatory and anti-cancer properties.

Prior to the PU microstructure synthesis, the antioxidant activity of the extract was evaluated. A high antioxidant activity was remarqued for the $1 \mathrm{mg} / \mathrm{mL}$ and $0.5 \mathrm{mg} / \mathrm{mL}$ extract solutions (fig. 1), with values similar to ascorbic acid (91\% versus $96 \%)$. The high antioxidant activity of Japanese knotweed investigated in the current study (collected in Romania) is in agreement with results obtained on plant material from Asian plants [29] and previous data on the antioxidant activity of young rhizomes with smaller diameter [30].

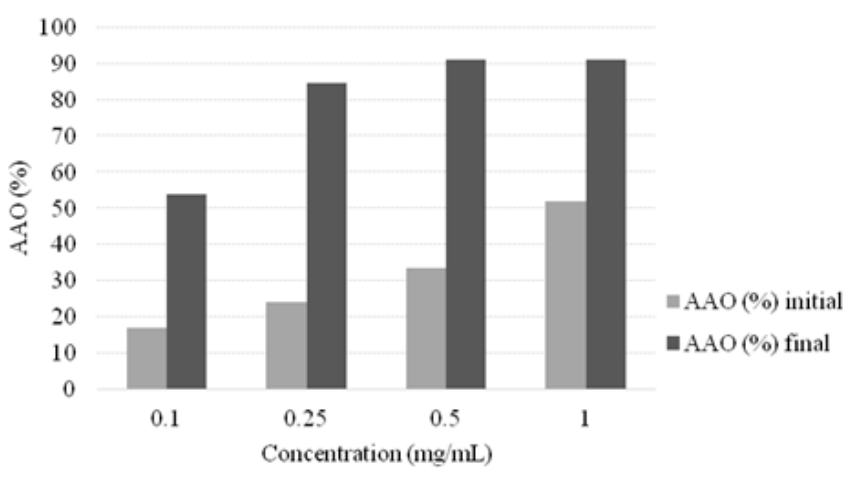

Fig. 1. The antioxidant activity of J apanese knotweed extract at different concentrations

The $p \mathrm{H}$ values of $\mathrm{PU}$ microstructures solutions were evaluated in triplicate and the following values were obtained: $6.87 \pm 0.12$ (empty microstructures) and $6.92 \pm 0.14$ (sample of PU microstructures containing Japanese knotweed extract); both samples present $\mathrm{pH}$ values which are specific for medical purposes. 
Table 1

ZETASIZER CHARACTERIZATION OF PU MICROSTRUCTURES

\begin{tabular}{|c|c|c|}
\hline Sample & $\begin{array}{c}\text { Particle size } \\
(\mathbf{n m})\end{array}$ & $\begin{array}{c}\text { Zeta potential } \\
(\mathrm{mV})\end{array}$ \\
\hline Empty microstructures & $540 \pm 11$ & $-29.4 \pm 0.2$ \\
\hline $\begin{array}{c}\text { Microstructures containing } \\
\text { Japanese knotweed extract }\end{array}$ & $1134 \pm 19$ & $-25.7 \pm 0.7$ \\
\hline
\end{tabular}
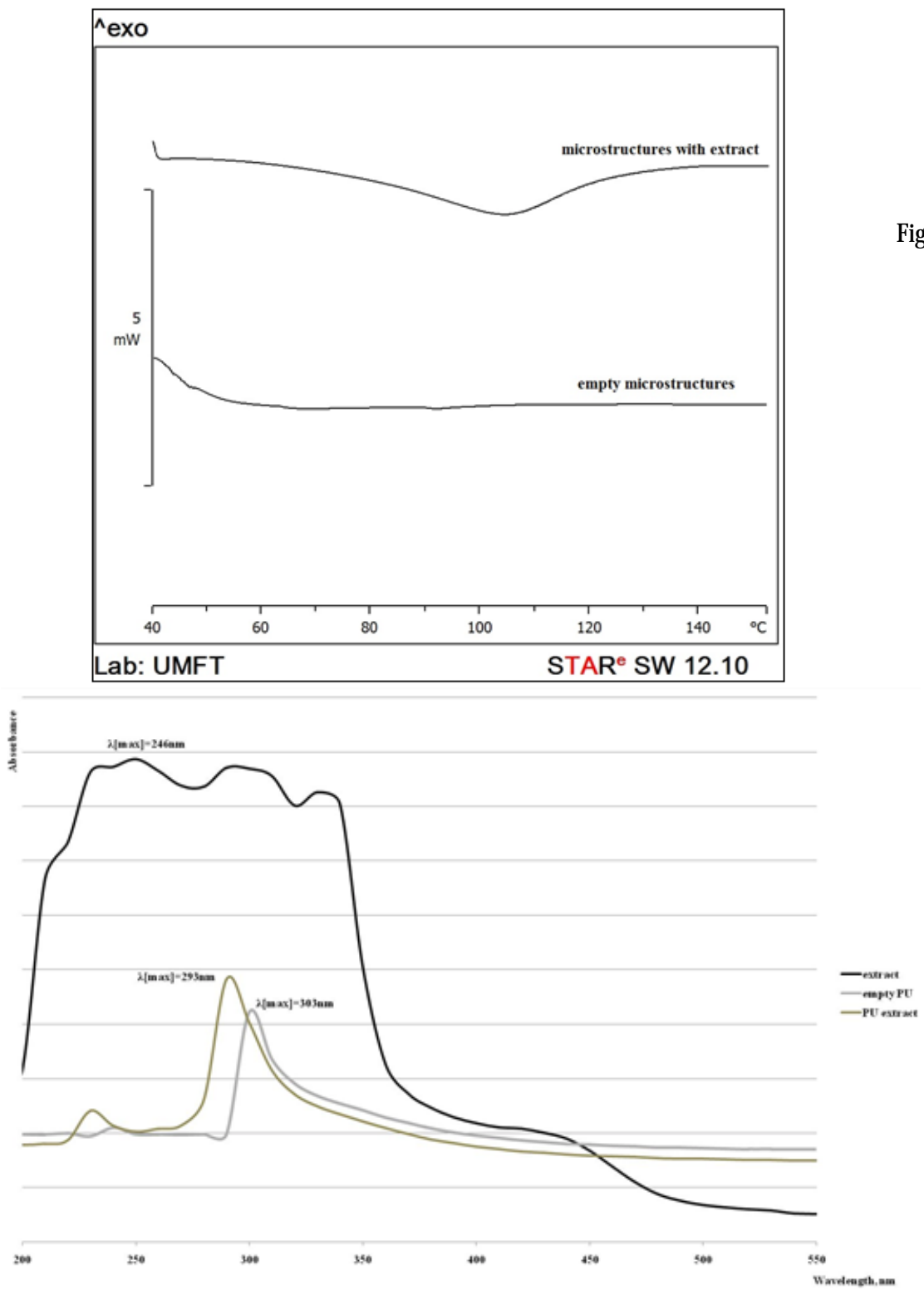

PU microstructures containing J apanese knotweed extract were synthesized by interfacial polyaddition combine with spontaneous emulsification. The size of PU microstructures and Zeta potential are presented in table 1.

The PU microstructures containing J apanese knotweed extract showed larger sizes, indicating the intercalation of polyphenolic compounds from the extract inside the polymer chain. The Zeta potential of microstructures containing the extract indicates a medium stability against agglomeration (Zeta potential in the range 20-30 mV), while the empty PU structures present a higher stability [31].

Differential scanning calorimetry (DSC) analysis was performed between 40 and $150^{\circ} \mathrm{C}$ because this is the temperature interval of main thermal peaks of polyphenols. Figure 2 revealed no important changes due to the stability of PU microstructures in the studied domain.

The efficacy of encapsulation was evaluated as UV-Vis absorbance as a function of extract concentration. The

Fig. 2. The DSC curves of empty microstructures sample and of sample of microstructures containing J apanese knotweed extract

Fig. 3. UV-Vis spectra of the analysed extract and PU microstructures' samples 
Characterization of DSC thermograms revealed the stability in the studied range. Further studies evaluating the in vitro and in vivo activity of the synthesized polymer-based structures shall establish their utilisation for targeted delivery of knotweed extract.

Acknowledgements: The reagents and instruments used for the polyurethane microstructures synthesis were purchased using the financial support offered by Victor Babes University of Medicine and Pharmacy Timisoara, Romania (internal competition grant no. 15250/ 2012).

\section{References}

1.FAN, P., HAY, A. E., MARSTON, A., LOU, H., HOSTETTMANN, K., Biochem Syst Ecol, 37, nr.1, 2009, p.24-34.

2.BOZIN, B., GAVRILOVIC, M., KLADAR, N., RAT, M., ANAĖKOV, G., GAVARIC, N., J. Serb. Chem. Soc., 82, nr.7-8, 2017, p.803-813 3.EL-READI, M.Z., EID, S.Y., AL-AMOUDI, H.S., WINK, M., J Tradi Med Clin Natur, 5, nr.3, 2016, p. 193

4.KURDVIETIENE, L., STANEVIÈIENË, I., MONGIRDIENË, A., BERNATONIENË, J., Medicina (Kaunas), 52, nr.3,2016, p.148-55.

5.PENG, W., QIN, R., LI, X., ZHOU, H., J Ethnopharmacol. 148,2013, p.729-745.

6.WATKINS, R., WU, L., ZHANG, C., DAVIS, R.M., XU, B., Int J Nanomedicine, 10, 2015, p.6055-74.

7.MAHAPATRO, A., SINGH, D.K., J Nanobiotechnology, 9,2011, p.55. 8.ZDRAHALA, R.J., ZDRAHALA, I.J ., J BiomaterAppl, 14, nr.1, 1999, p.67-90.

9.ULERY, B.D., NAIR, L.S., LAURENCIN, C.T., J Polym Sci B Polym Phys. 49, nr.12, 2011, p. 832-864.

10.CRAINICEANU, Z.,IANES E., MATUSZ P., BLOANCA V., SELEACU, E., NARAD, V.., NARAD, G., NODITI, Gh., BRATU, T., Innovative Method of Titanium Plate Use for Morphological and Functional Human Face Recontruction, Mat. Plast.,53, no. 3, 2016, p.518

11.TEODORESCU-DRAGHICESCU, H., VLASE, S., STANCIU, M.D., CURTU, I., MIHALCICA, Advanced Pultruded Glass Fibers-Reinforced Isophtalic Polyester Resin, M., Mat. Plast.,42, no. 1, 2015, p.62 12.SONG, E.H., J EONG, S.H., PARK, J.U., KIM, S., KIM, H.E., SONG, J., Mater Sci Eng C Mater Biol Appl. 79, 2017, p.866-874.

13.ZHANG, Y., ROCHEFORT, D., J Microencapsul, 29, nr.7, 2012, p.63649.

14.CHEN, X., LIU, L., JIANG, C., Acta Pharm Sin B, 6, nr.4, 2016, p.2617.

15.BURKE, A., HASIRCI, N., Polyurethanes in Biomedical Applications. In: Hasirci N., Hasirci V. (eds) Biomaterials. Advances in Experimental Medicine and Biology, vol 553. Springer, Boston, MA, 2004.
16.BORCAN, F., SOICA, C.M., GANTA, S., AMIJI, M.M., DEHELEAN, C.A., MUNTEANU, M.F., Chem Cent J, 6, nr.1, 2012, p.87.

17.MUNTEANU, M.F., ARDELEAN, A., BORCAN, F., TRIFUNSCHI, S.I., GLIGOR, R., ARDELEAN, S.A., CORICOVAC, D., PINZARU, I., ANDRICA, F., BORCAN, L.C., Curr Drug Deliv, 14, 2017, DOI : 10.2174/ 1567201814666170126113231.

18.OPREAN, C., BORCAN, F., PAVEL, I., DEMA, A., DANCIU, C., SOICA, C., DEHELEAN, C., NICU, A., ARDELEAN, A., CRISTEA, M., IVAN, A., TATU, C., BOJ IN, F., In Vivo, 30, nr.5, 2016, p.633-8.

19.OPREAN, C., ZAMBORI, C., BORCAN, F., SOICA, C., ZUPKO, I., MINORICS, R., BOJ IN, F., AMBRUS, R., MUNTEAN, D., DANCIU, C., PINZARU, I.A., DEHELEAN, C., PAUNESCU, V., TANASIE, G., Pharm Biol, 54, nr.11, 2016, p.2714-2722.

20.YAMAOKA, T., MAKITA, Y., SASATANI, H., KIM, S.I., KIMURA, Y., J Control Release, 66, nr.2-3, 2000, p.187-97.

21.YUAN, J., LAN, T., LIU, J., WANG, G., SUN, Q., CHEN, H., REN, J., ZHANG, J., SUN, L., BiomedRes, 26, nr.3, 2015.

22.JI, Q., LIU, X., FU, X., ZHANG, L., SUI, H., ZHOU, L., SUN, J., CAI, J., QIN, J., REN, J., LI, Q., PLoSOne, 8, nr.11, 2013, p. e78700.

23.RAHAL, K., SCHMIEDLIN-REN, P., ADLER, J., DHANANI, M., SULTANI, V., RITTERSHAUS, A.C., REINGOLD, L., ZHU, J., MCKENNA, B.J., CHRISTMAN, G.M., ZIMMERMANN, E.M., Inflamm Bowel Dis, 18, nr.4, 2012, p.613-23.

24.MISHRA, K., OJHA, H., CHAUDHURY, N. K., Food Chemistry, 130, nr.4, 2012, p.1036-1043.

25.BOUCHEMAL, K., BRIANCON, S., PERRIER, E., FESSI, H., BONNET, I., ZYDOWICZ, N., Int. J. Pharm., 269, 2004, p. 89-100.

26.BORCAN, F., SOICA, C.M., DEHELEAN, C.A., GANTA, S., AMIJI, M.M., Rev. Chim, (Bucharest), 63, no.11, 2012, p.1164

27.DANCIU, C., BORCAN, F., SOICA, C., ZUPKO, I., CSANYI, E., AMBRUS, R., MUNTEAN, D., SASS, C., ANTAL, D., TOMA, C., DEHELEAN, C., Nat. Prod. Comm., 10, nr.6, 2015, p.951-954.

28.ZHANG, H., LI, C., KWOK, S. T., ZHANG, Q. W., CHAN, S. W., Evid Based Complement Alternat Med, 2013.

29.LIN, Y. W., YANG, F. J., CHEN, C. L., LEE, W. T., CHEN, R. S., J Nat Med, 64, nr.2, 2010, p.146-152.

30.ARDELEAN, F., MOACÃ, E. A., PÃCURARIU, C., ANTAL, D. S., DEHELEAN, C., TOMA, C. C., DRAGAN, S., Studia Univ VG Arad, SSV, 26, nr.4, 2016, p.415-42.

31.CITU, I.M., TOMA, C., TRANDAFIRESCU, C., ANTAL, D., ZAMBORI, C., OPREAN, C., BOJIN, F., BORCAN, F., PÃUNESCU, V., LAZUREANU, V., Rev. Chim. (Bucharest), 66, no. 3, 2015, p.431

Manuscript received: 28.07 .2017 